\title{
Sustainable Use of Water in Urban Design
}

\section{Kentsel Tasarımda Suyun Sürdürülebilir Kullanımı}

\author{
Research Article
}

\section{Demet Demiroğlu'*, Ayşen Çoban', A. Esra Cengiz²}

'Kilis 7 Aralık University, Faculty of Engineering and Architecture, Department of Landscape Architecture, Kilis, Turkey. ${ }^{2}$ Çanakkale 18 Mart University, Faculty of Architecture and Design, Department of Landscape Architecture, Çanakkale, Turkey.

\section{A B S T R AC T}

U rban ecosystems have changed considerably nowadays, due to increasing population growth and dense settlements. These changes have caused the depletion of resources and disruption of natural balance. "Water Efficient Urban Design" or "Sustainable Urban Drainage Systems" are the most important approaches in order to prevent the most vital resource, water to reach a point where it is exhausted. In this study, the aforementioned approaches are explained and examples around the world are discussed.

\section{Key Words}

Water, Sustainability, Water Efficient Urban Design, Sustainable Urban Drainage Systems.

\section{ÖZET}

ünümüzde yaşanan nüfus artışı ve yoğun yapılaşma ile kentsel ekosistemler büyük ölçüde değişmiştir. $\exists$ Bu değişimler kaynakların hızla tükenmesine ve doğal dengenin bozulmasına neden olmuştur. En önemli yaşamsal kaynak olan suyun, giderek tükenme noktasına gelmesinin engellenmesindeki en önemli yaklaşımlar "Su Etkin Kentsel Tasarım" veya "Sürdürülebilir Kentsel Drenaj Sistemleri"dir. Bu çalışma kapsamında söz konusu yaklaşımlar açıklanmış ve dünya'daki örnekler tartışıımıştır.

\section{Anahtar Kelimeler}

Su, Sürdürülebilirlik, Su Etkin Kentsel Tasarım, Sürdürülebilir Kentsel Drenaj Sistemleri

Article History: Received: Jun 22, 2015; Revised: Dec xx, 2015; Accepted: Mar 20, 2016; Available Online: Apr 1, 2016.

DOI: $10.15671 /$ HJBC.20164418128

Correspondence to: D. Demiroğlu; Kilis 7 Aralık University, Department of Landscape Architecture, Kilis, Turkey. 


\section{INTRODUCTION}

Irbanization, causing the green areas to turn into constructed environment, affects the natural landscape considerably. During this period, new impermeable surfaces like buildings, roofs, roads, bicycle roads, pavements, squares and parking areas are formed [1]. These surfaces change the natural water cycle and cause various environmental problems [1,2]. These problems are; changing hydrology form, climactic changes, water and food scarcity, urban heat islands. To solve these problems, water efficient urban design and sustainable urban drainage system strategies should be adopted. Via these strategies, the quality of water improves, the flow of water is controlled and use of water decreases [2]. In this context of the study, design strategies for the sustainability of cities and effective use of water are discussed and the application examples concerning these approaches around the world are examined.

\section{MATERIALS AND METHODS}

Literature review about this study was carried out and within the scope of the related literature, "Water Efficient Urban Design" or "Sustainable Urban Drainage Systems" were explained. Water Efficient Urban Design and Sustainable Urban Drainage System strategies were explained one by one and the examples around the world were examined.

\section{RESULTS}

\section{Water}

Water is one of the most indispensable elements of life. Most of the living organisms are made up of water. All of the vital activities are possible with water [3]. Water resources have been the basic criteria for the choose of living spaces throughout the history [4]. Water, being used in agricultural activities started with the first age civilizations, expressed in various ways in garden arrangements and architectural structures and gained different meanings in time [5].

It is impossible to tell the structure of humans and cities without water [4]. The use of water for agricultural activities, drinking, hygienic means changed form in urban structure and turned into something that amused, relaxed, comforted, provided psychological wellbeing, sometimes showed status and sometimes had monumental meaning [5].

Water being one of the most important elements of landscape is used for easing the intense atmosphere of the cities that grow incrementally in parallel with the rapidly developing technology. Water is used in agriculture for aesthetic purposes, visual purposes, audial purposes, psychological effects, functional purposes, noise management, circulation management, climactic data and recreational purposes [5]. However, the water problems caused by climactic changes and global warming increase water stress. The biggest effect of urbanization on water is the fact that vegetation covers like forests and pastures are being replaced by the impermeable structures like roads and buildings [6].

\section{The Principles for Effective Use of Water}

The facts that the natural resources in the urban areas are being destroyed by the rapid population growth and urbanization both in the world and in our country, current natural resources are not used efficiently in urban areas diminish the level of life quality in cities and harden the sustainability goals [7]. Especially in recent years, the pressure on water has been increasing rapidly [6]. It is possible to ease or completely remove this pressure via efficient use of water, which is the basic principle of the sustainable design, and water efficient urban design and sustainable urban drainage system strategies.

Water efficient urban design is a urban planning and design approach that aims at protecting water systems and minimize the effects on the natural water cycle [8]. Water efficient urban design defines the water flows that are in the water cycle as valuable resources. These water flows are defined as rain water (gathers on roofs), flow (containing rain water, gathering on every impermeable surfaces), drinking water, grey water (coming from bathroom taps, shower and laundries), black water (coming from washbasins and toilets) [9]. Water effective urban design represents a change in the way of urban 

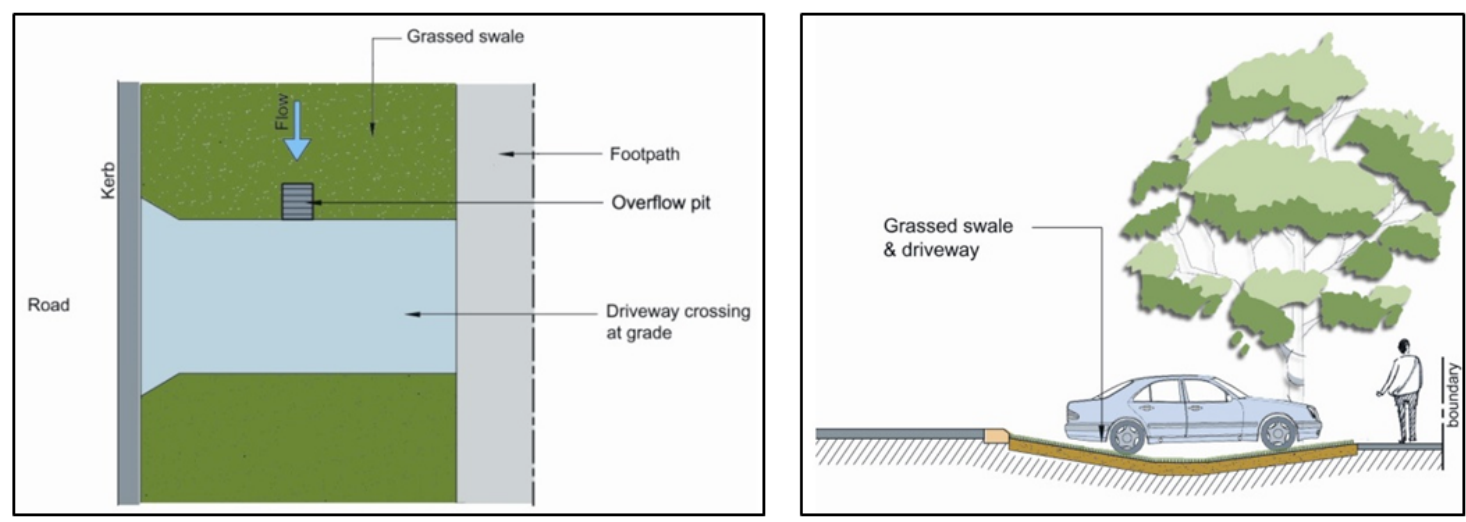

Figure 1. Plan and section of swale application [14].

development that is thought, planned, designed and built and it helps to eliminate most of the potential negative effects of urban development on the natural water cycle [8].

In this context, the goals of water efficient urban design are as follows [8-10];

- Minimizing the risk of overflows in urban areas, - Preventing erosion on water courses and slopes, - More efficient use of water resources,

-Maintaining the infrastructure of water, rain water and waste water,

-Re-use of rain water, waste water, ground water and grey water as alternative resources and use of water efficient applications for maintaining the supply of drinking water,

-Keeping the rain water instead of letting it flow, -Re-use, storage and infiltration of rain water instead of much use of drainage systems,

- Using vegetation to filtrate rain water,

-Designing water efficient landscape to diminish water consumption,

-Protecting the recreational values of water, coastal ecosystems and running waters,

-Protecting and restoring the aquatic and drought ecosystems.

A successful "Sustainable Urban Drainage Systems" is beneficial for various aspects, changes the life quality in the environment where people live, increases biodiversity, diminishes the risk of flood and is very resistant towards the effects of climactic changes. Sustainable drainage systems is an approach that is preferred for the management of rain water running on hard surfaces. The basic goal of the sustainable urban drainage systems is to imitate the natural drainage system of an area [11].

\section{Water Efficient Urban Design Strategies Swales and Buffers}

Swales are straight collapse areas. They eneble rain water to be gathered and carried. These swales, formed by the channels with pastures and vegetation, help to carry the flow on impermeable surfaces and they are linear, shallow and wide $[12,13]$. Functions of swales are [12];

- Carriage of rough and middle height sediments along the plant surface via filtration,

-Diminishing the flow volume,

- Delaying the flow peaks by decreasing flow speed, - Complying with the pedestrian movements along the swales.

Swales convey the water by decreasing its speed on impermeable surfaces and inclined areas form a connection between water courses and impermeable surfaces. Hence, they help to protect the water courses. In practice, swales are designed as conveyance means and they are most suitable on the residential areas with much less density, wide highway borders or areas with land flow in open areas. These swales are used as braking and groove alternatives [12]. In the Figure 1, there is the plan and section of a ditch application on an inclined private car way or in front of a garage.

Buffer zones or strips are known as filtration strips. These strips are lawny or planted areas. 


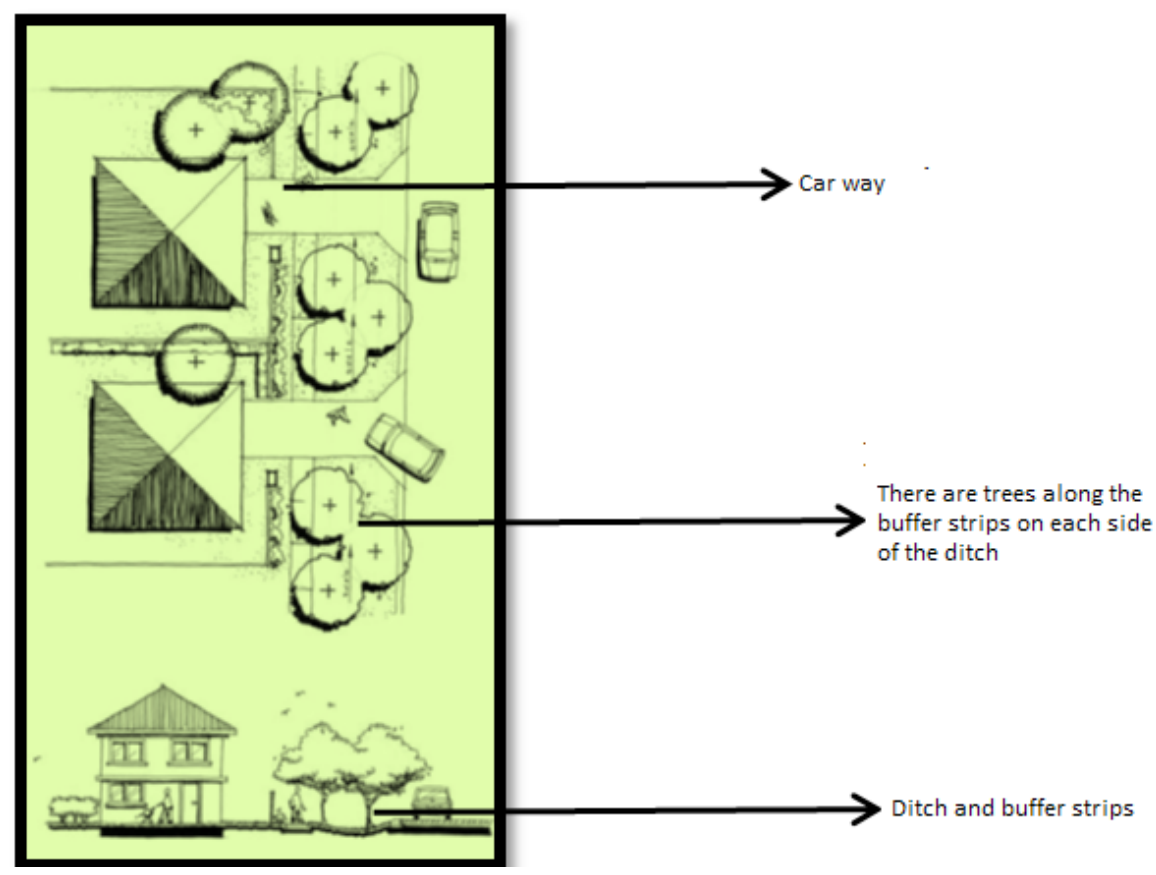

Figure 2. Swale and buffer strip [15].

Buffer strips are wide, inclined areas with open vegetation. Buffer strips carry sediments, some nutrition and hydrocarbons. These strips are used near the ditches. Buffer strips are like ditches, but these strips are not used to convey the flow. The functions of buffer strips are [12];

- Carrying the sediments along the vegetation via filtration,

-Decreasing the flow volume,

- Decreasing the flow speed,

-Being covered with the appropriate vegetation and variety.

Buffer strips are used on refuge and road borders, parking areas, park and recreational areas to carry the rain water into the swales (Figure 2) $[12,13]$.

\section{Bioretention Systems}

Bioretention systems are water efficient urban design criterions. They enable rain water penetrate under the ground or gather under the ground, keep rain water flow away from various contaminators and decrease the flow speed by enabling rain water infiltration $[16,17]$. Bioretention systems are generally applied as bioretention swales and basins [16]. Bioretention swales are bioretention systems and they are placed on bases of swales (Figure 3).
The inclines of the swales varies between $1 \%$ and $4 \%$. Swales decrease water flow speed and potential erosion $[10,16]$. Bioretention basins provide flow control and water quality (Figure 4) [16].

The basic functions of biological water retention systems are keeping the water quality, protecting the water and increasing the installation. Small volumes of the systems control floods. The vegetations contained by this system add some nutrition and polluters into the rain water flow and turn the polluters into less harmful components by destroying their structures with their roots $[16,17]$. Other functions of these systems are [16];

- Carrying the poor quality sediments and infiltrating the polluters with the help of surface vegetation and ground covers,

- Carrying the thin particles and infiltrating the polluters with the help of the filter layer under the ground,

- Having an aesthetic value due to the vegetation,

- Forming a qualified habitat for wild life and increasing the bio-diversity.

Biological water retention systems are used on streets and motorways. Other fields of their use are parks, car parks, road sides along the highway corridors and central refuges [16]. 


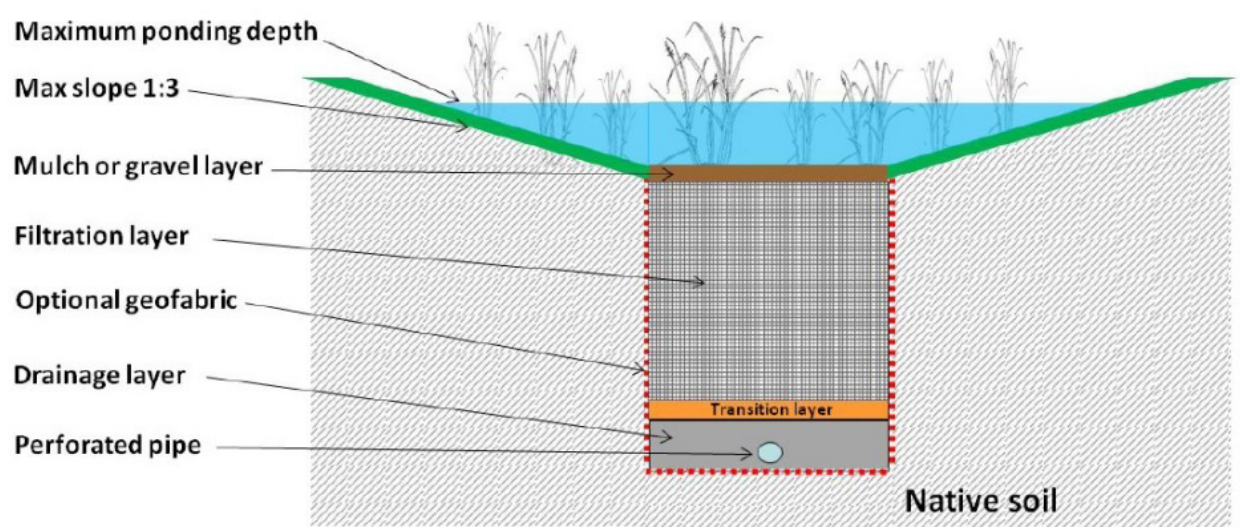

Figure 3. Bioretention swale[16].

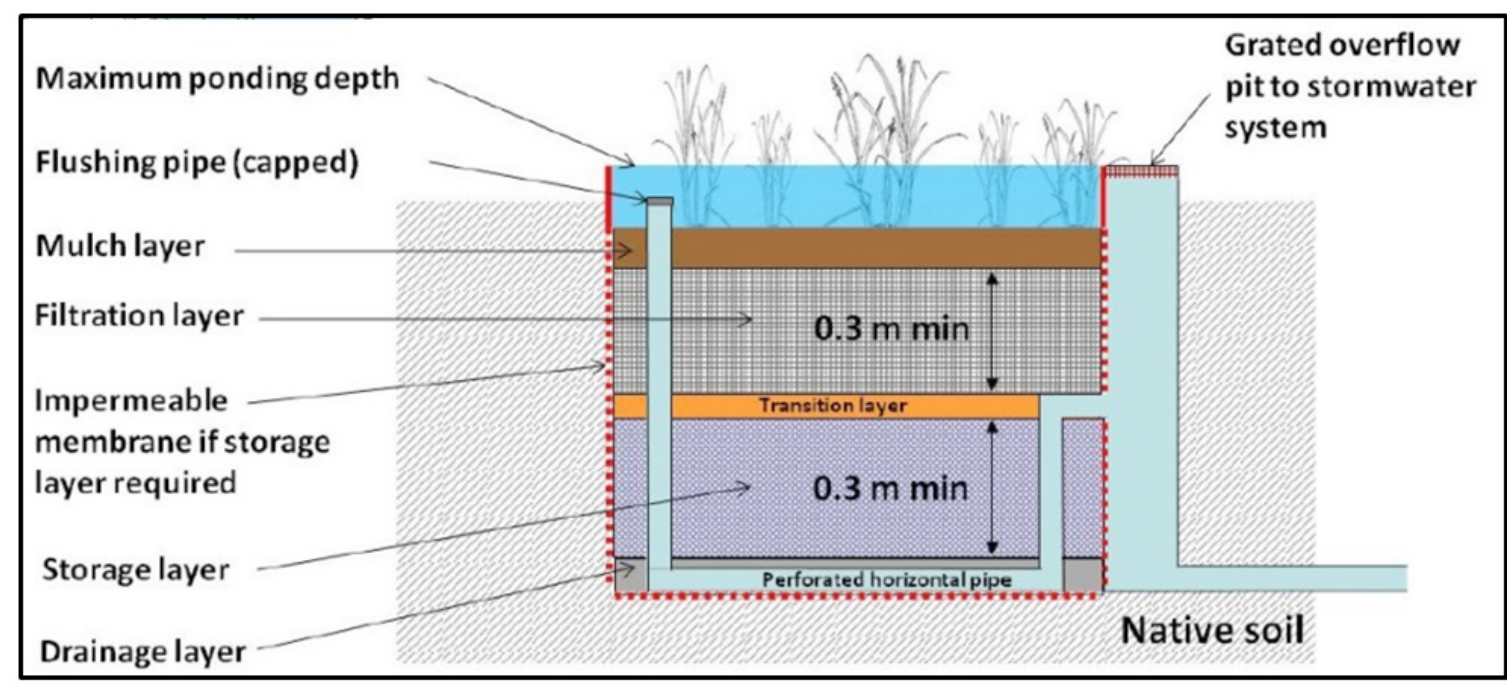

Figure 4. Bioretention basin [16].

\section{Artificial Wetlands}

Artificial wetlands are engineering systems. Designing wetlands is important for making use of the natural processes of the vegetation, soil and microbial clusters related to the natural wetland. Artificial wetlands are able to gain the functions of natural wetlands [18]. Artificial wetlands provide habitat, recreation and temporal water storages for reuse [19].

Wetlands are generally composed of entrance zone (sediment pool), macrophyte zone (an area with shallow and dense vegetation) and passing channel with high flow ( the area that protects macrophyte zone from erosion and vegetation harm) [10]. The aims of wetlands are [19];

- Compensating the loss of natural wetlands because of agriculture and urban growth,
- Keeping and improving the water quality,

- Keeping overflows under control,

- Developing the habitats by supporting water life and wild life,

- Providing recreational activities.

Artificial wetlands should be designed on areas that have enough water inflow, not on dry lands [19]. One of the important functions of wetlands is ameliorating the wastes. A great number of scientists suggested that wetlands can be used for processing the domestic wastes. There are some wetlands that are used for that reason. For example; according to U.S. Department of Interior (1984), the Brillion Marsh has been collecting domestic sewage wastes since 1923 [20]. 


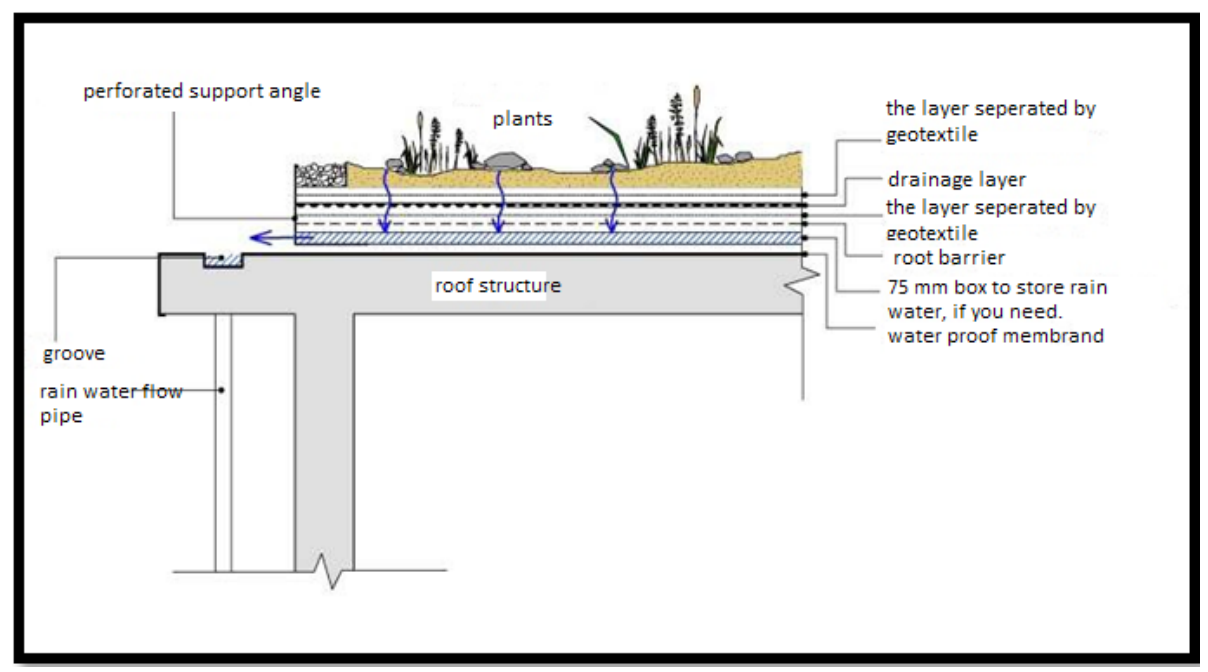

Figure 5. Roof garden [22].

\section{Roof Gardens}

They are the areas that are located on the tops of buildings and contain living vegetation layer growing on the surface of drainage layer. Their functions are [21];

- Directing the flow,

- Protecting and improving the water quality,

- Decreasing the impermeable areas,

- Decreasing the heat island effect,

- Diminishing the air pollution,

- Developing the bio-diversity,

- Increasing the level of oxygen,

- Forming living areas.

Roof gardens (Figure 5) can be applied on the roofs of industrial and commercial areas and roofs of residents.

\section{Rain Gardens}

They are specially designed garden beds. They are porous, have sand and loam bases, have various plant species on them and are appropriate for their regions. Rain gardens are suitable for rough sediments, hard materials and heavy metals, but they are limited areas for hydrocarbon capacity. These gardens (Figure 6) are aesthetically good looking, along with their functional aspects [23].

Rain gardens gather rain water from roofs and other buildings and help the flow by enabling the infiltration of water under the soil. Rain gardens should be designed with the natural plant species pecu- liar to the region or sustainable species that are suitable for the regional climactic conditions should be used. Chemical, biological and physical qualities of the plants, microbial living creatures and soil enable water penetrate into the soil by being filtered and the polluters in the water are destroyed thanks to these qualities [21].

\section{Infiltration Systems}

They are composed of shallowly dug water ways (Figure 7) or tanks. The function of infiltration systems are decreasing the flow, diminishing the pollution and gathering rain waters. Infiltration system infiltrates the flow and stores it and decreases the flow volume of water. These systems diminish the pollution on urban water ways in two steps. They are [21].

-Minimizing the flow from urban gathering surfaces to water ways,

-Preventing pollution from entering the urban drainage networks.

\section{Permeable Surfaces}

The porous pavements, which are used as alternatives for pavement areas, or the spaces combined with vegetation absorb the flows. They keep dirty rain water away from sediments, some nutrition and heavy metals. Permeable surfaces are used in car parks and walking areas [25]. In Figure 8 , it can be seen that permeable surfaces are used on pavements and house gardens. 


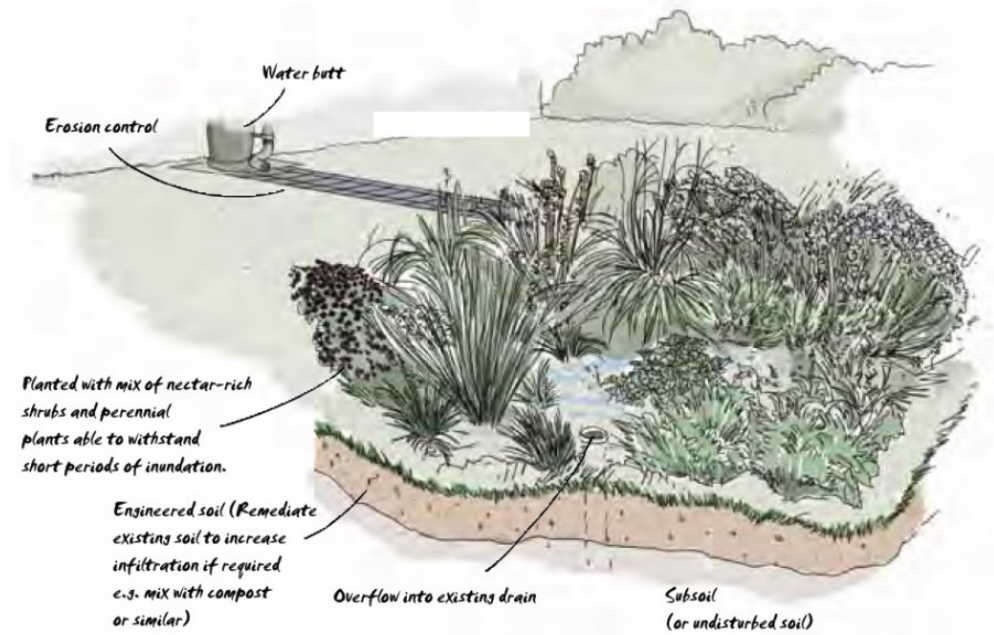

Figure 6. Rain garden [24].

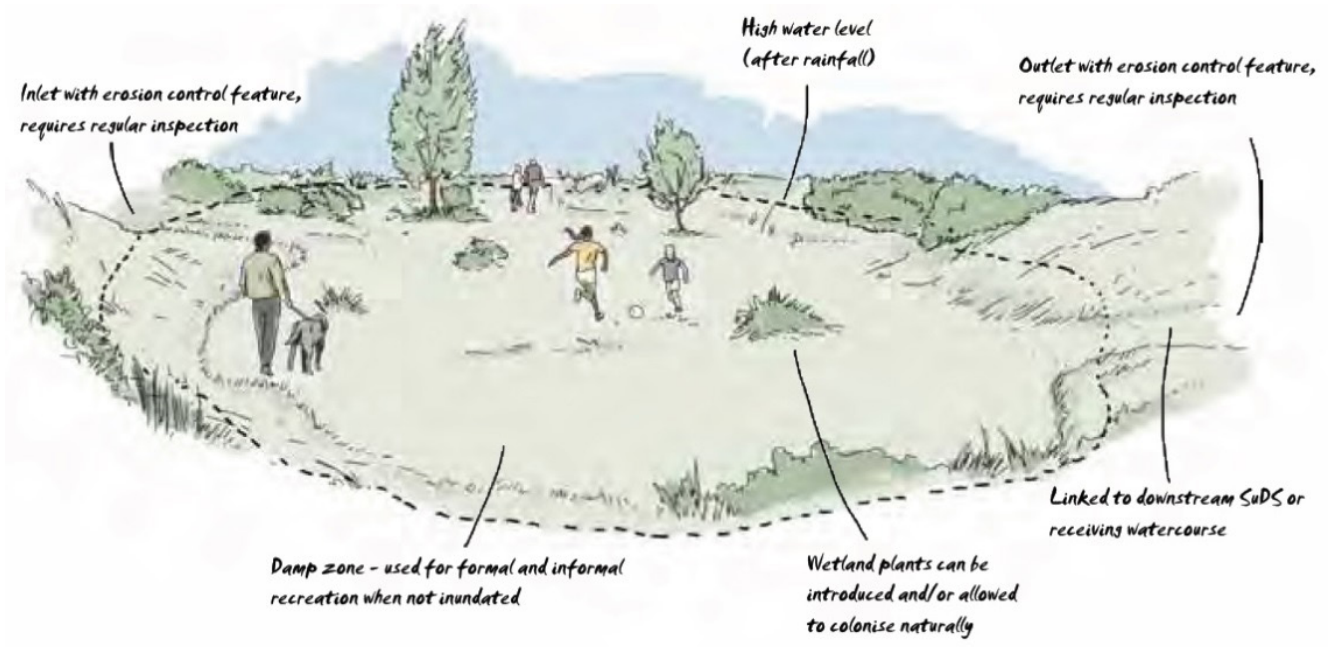

Figure 7. Water catchment [24].

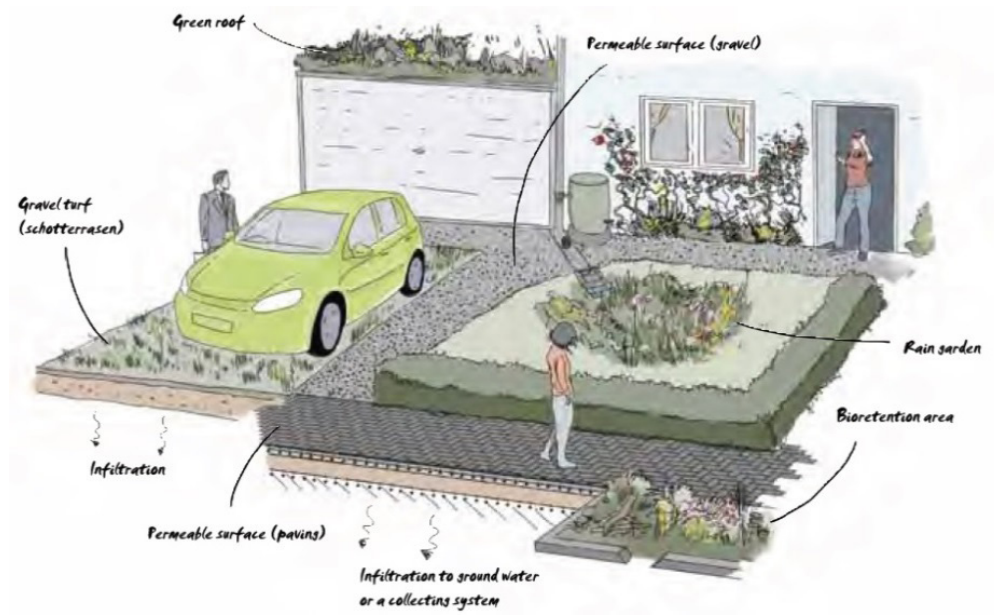

Figure 8. Permeable surfaces and water efficient urban design strategies [24]. 


\section{Examples of Water Efficient Urban Design in the World Waternet Central Office/Amsterdam}

One of the two towers of Waternet Central Office in Amsterdam gathers the rain water falling on buildings via a catchment. Waternet is an example that does rain water buffering in the closed building areas in its own facility. Waternet is responsible for providing drinking water and processing waste water as the administrator of water supply network of Amsterdam. Water concept was intended for the Waternet building located along the Amste River. The construction that was realized for that intent was finished in 2005 and became an example of rain water buffering and processing without a center. Open rain water buffering was done in an area of $1400 \mathrm{~m}^{2}$ below one of the towers. Water buffer covers a great part of the $1880 \mathrm{~m}^{2}$ area. The water buffer has two functions [26]:

- Storing water temporally after filtration and before being drained into Amstel River,

- Storing grey water for using inside the building.

\section{Portland/Oregon}

Portland city has a long history of a comprehensive planning including urban design, public transportation and green infrastructure systems. In Portland, which has green streets, components containing vegetation are used for managing rain water flow. Portland offers various examples with its well-designed green streets. SW 12 Ave Green Street Project, which was realized in 2005, includes the studies of improving rain water management via plants inside the city. This project shows environmental, aesthetic and functional benefits of the current or new streets by associating them with urban streetscape in densely urbanized regions $[27,28]$.

\section{Queen Botanical Garden/New York-USA}

The master plan of Queen Botanical Garden in 2001 started the Sustainable Landscapes and Buildings Project [29]. In this project, the sustainable approach of water management has an outstanding place $[30,31]$. Sustainable Landscapes and Buildings Project includes the new plants, most of which are natural species, biological ditches for gathering rain water and reuse of grey water [29]. Minimizing the demand of drinking water and removing the overflow of rain water are aimed throughout the area. All of the roof surfaces in the area feed the rain water gathering system of the area; the gathered water is cleaned through the vegetation and pebble surface layer, which form a part of the landscape, and this processed water is used as a water resource for many plants. Along with that, the grey water in the area is reused by being purified with the appropriate plants $[30,31]$.

\section{Beam Park Areas/Dagenhan-England}

Beam Park areas, which are 53-hectare, is a multifunctional wetland park that is located on the flood plain caused by Beam River and Wantz Stream. The basic functions of these areas are forming a defense mechanism against floods, protecting and improving the bio-diversity and providing recreational facilities for the local people by forming a green infrastructure system [32].

\section{Springhill Communal Residences/Stroud/ Gloucestershire-England}

Springhill Residences are environmentally friendly residences that support a communal life. In the area where Springhill Residences are located, there is "Sustainable Urban Drainage Systems". These are [24];

- Permeable surfaces,

- Drainage ditches,

- Stepped surfaces,

- Ditches with vegetation,

- Open channels and brooks,

- Raised ornamental pools,

- Water retention pools.

In the area where these residences are located, water flow is downwards in line with the incline. Access areas and car parks are generally defined as the areas that form basic risk of pollution. However, the permeable surfaces that are used in Springhill Residence Area gather and store the rain water in a tank located under the surface. New designs and strategies that are realized in Springhill Residences generally include engineering solutions.

These are [24];

- Placing pipes in brooks and ditches,

- Using open storage features, 
- Placing underground tanks in multi-functional areas,

- Sustainable urban drainage systems making infiltration possible on the clay-dominant areas when natural shrinkage occurs.

\section{Lamb Drove/Cambourne/Cambridgeshire- England}

Lamb Drove is composed of 35 residences and covers 2.5-hectare area of Cambridgeshire Region. "Sustainable Urban Drainage Systems", which can be used in areas thet are exposed to flood risk, show a reinforcement scheme. The designed scheme [24];

- Variety of sustainable urban drainage system techniques,

- Effective protection of residences against flood,

- Effective design cost,

- Easy management of sustainable urban drainage systems,

- Bio-diversity and many benefits.

Use of "Sustainable Urban Drainage Systems" in the area considerably decreases the surface flow, improves the water quality, provides bio-diversity, decreases the cost and forms open green areas around the residences [24].

\section{Greener Grangetown/Cardiff-England}

Grangetown in Cardiff is a neighborhood harboring social and cultural variety. The surface water in the area is gathered in a combined network and purification process is carried out without energy and carbon cost by pumping the water to Cog Moor waste water purification facility 8-mile away. "Water Efficient Urban Design" strategies in this area are ditvhes, biological pools, permeable surfaces and curb drainage. To develop the gardens, the hoby gardens, the picnic areas and the recreational places in this area, the related strategies should be evaluated [33].

\section{Royal Park Wetland/Melbourne-Australia}

Royal Park rain water gathering project is the most successful rain water gathering project of Melbourne. This project is used for irrigation by filtering urban surface water flow for the legacy of Melbourne City. Rain water is routed by being drained and is gathered 187-hectare catchment basin. Routing structure is also a sediment trap. This routing structure allows low flow in the 0.8-hectare artificial wetland. After the flow, the water, which is purified in $12 \mathrm{ml}$ storage basin, is allowed to be carried in Moore Ponds Creek. The $5 \mathrm{ml}$ underground tank, which is located below the sport areas, was built in this storage area in 2008. The water being kept in the distribution tank is purified with UV beam and is used for irrigating the adjacent golf pitch and oval sand park area [34].

\section{Upton/Northampton-England}

England helps the landscape based drainage order sustainable urban development, which is used in Northampton, be successful. The urban development planning of Upton, which is located on south-west foothills of Northampton in the East Midlands region of England, is based on a landscape model. In this landscape model, "Sustainable Urban Drainage Systems" are applied. Sustainable Urban Drainage Systems emphasizes on controlling and limiting the surface water flow. These are possible with roofs, pipe systems, ditches, combined pools and permeable surfaces, which are all "Sustainable Urban Drainage Systems" and "Water Efficient Urban Design" strategies. These strategies prevent rain water flow into sewages [35].

\section{London 2012 Olympic Park/England}

One of the goals of basic water strategies is to decrease drinking water consumption by $40 \%$ according to the industrial standards. The goal was achieved via water efficiency, reuse of water and combination of the criterion of water translocation and water saving was done at the rate of $57 \%$. With the effective use of water in the indoor places, water saving was achieved at the rate of $20 \%$; for example, rain water gathering precautions were taken to clean toilets. Impotable water networks were used for irrigation of parks, cleaning toilets by purifying the sewage water. Hence, drinking water consumption was decreased by $37 \%$. Risk of flood was diminished by combining the surface water with drainage systems and sewage lines, and the quality of river water was enhanced [33].

\section{DISCUSSION}

Karadağ and Uzun (2009) stated that one of the most natural resources especially for all living beings was water-based resources and sustainability of life was only possible with the presence of water [36]. Water 
and water-based resources are primary importance for human and ecosystem health/use, economic development, energy generation, etc. and they are indispensable. Because of growing urbanization today, various dramatic and permanent changes can occur for soil, water and air, which are the most important sources of life. The most basic reason for this is the fact that urban planning and designs are shaped just to meet daily needs and away from the point of sustainability, rather than being applied for the long run. However, it is possible and easy to protect the resources of life and leaving a clean and sustainable environment for the next generation via correct and reasonable planning-design approaches.

In this century, water and water-based resources are still important and it can be seen that water has reached to a point of being strategically important because of the growing world population and their unmet needs [37]. For this reason, reasonable use of water in urban designs is one of the primary subjects. Sustainable use of water in urban design, which is one of the correct and reasonable urban design approaches, draws attention as one of the most important methods for preventing water, the vital resource for life, from running out. In this context, various applications within the scope of design are explained in the study in detail.

For the sustainable use and recycle of water, various solutions about the subjects like efficiency and recycle of water, controlled use of water, management of flood risk, waste water management, surface water management, increasing the quality of water should be suggested and applied within the design criterion. It should not be forgotten that the most important goal and base of the urban landscape design, like urban planning, is to protect the ecological balance and form a sustainable environment. Realization of this struggle will only be possible by using water, which is a resource of life and the most important of all, correctly, reasonably and unthreateningly in sustainable urban design studies.

\section{References}

1. L. Locatelli, O. Mark, S. Mikkelsen, K. ArnbjergNielsen, M.B. Jensen, P.J. Binning, Modelling of green roof hydrological performance for urban drainage applications, Journal of Hydrology, 519 (2014) 32373248.
2. S. Beecham, M. Razzaghmanesh, Water quality and quantity investigation of green roofs in a dry climate, Water Research, 70 (2015) 370-384.

3. E. Oktay, R. Erdoğan, Doğa, Su ve İnsan, TMMOB Peyzaj Mimarları Odası Yayını 2012/2013, (2012), 31-37.

4. F. Şavklı, T. Yılmaz, Evaluation of water supply possibilities for water structures in urban squares according to user preferences, Digital Proceeding Of THE ICOEST'2013 Cappadocia, 18-21 Haziran, Nevşehir (Turkey), 467-476.

5. G. Muratoğlu, Peyzaj Mimarlığında Su Kullanımı Yüksek Lisans Tezi, Ankara Üniversitesi, 2010.

6. Ö.L. Çorbacı, M. Özyavuz, M.E. Yazgan, Peyzaj Mimarlığında Suyun Akıllı Kullanımı: Xeriscape, Tarım Bilimleri Araştırma Dergisi, 4 (2011) 25-31.

7. G. Alhanlıoğlu, Kentsel Mekanda Su Elemanı:Boğaziçi'ne Dökülen Dereler, Yüksek Lisans Tezi, İstanbul Teknik Üniversitesi, 2006.

8. Anonymous, Water Sensitive Urban Design, Date of access: 27.02.2015. Accessed at: http://www. dcmtbarker.sa.gov.au/webdata/resources/files/Fact Sheet_3_Water_Sensitive_Urban_Design__Aug_2007. pdf, 2015a.

9. Anonymous, Water Sensitive Urban Design, Introdution, Chapter 1, Date of access: 23.03.2015. Accessed at:https://www.sa.gov.au/__data/assets/pdf_ file/0015/11364/WSUD_chapter_1.pdf, 2015b.

10. Anonymous, Evaluating Options for Water Sensitive Urban Design-A National Guide, Date of access: 24.02.2015. Accessed at:http://www.environment.gov. $\mathrm{au} /$ system/files/resources/1873905a-f5b7-4e3c-8f450259a32a94b1/files/wsud-guidelines.pdf, 2015c.

11. S. Wilson, B. Bray, S. Neesam, S. Bunn, E. Flanagan, Sustainable Drainage, Date of access: 14.04.2015. Accessed at: https://www.cambridge.gov.uk/sites/ default/files/docs/SUDS-Design-and-Adoption-Guide. pdf, 2006.

12. Anonymous, Water Sensitive Urban Design Technical Manual, Swale and Buffer Strips, Chapter 11, Date of access: 24.03.2015. Accessed at: https://www. sa.gov.au/_data/assets/pdf_file/0019/20917/WSUD_ chapter_11.pdf, 2015d.

13. Anonymous, , Melbourne Water, Swales, Date of access: 25.03.2015. Accessed at: http://www.melbournewater. com.au/Planning-and-building/Stormwater management/WSUD_treatments/Pages/Swales.aspx, 2015 e.

14. Anonymous, Swales and Buffers, Date of access: 30.03.2015. Accessed at: http://www.derwentestuary. org.au/assets/WSUD_Guidelines_-_Chap_7_-_Swales_ and_buffers.pdf, 2015f.

15. Anonymous, Gold Coast, Our Living City, Date of access: 28.03.2015. Accessed at: http://www.goldcoast.qld.gov. au/gcplanningscheme_0509/attachments/policies/ policy11/section_13_0_introduction_WSUD_guidelines. pdf, 2007.

16. Anonymous, Water Sensitive Urban Design Technical Manual Greater Adelaide Region, Bioretention Systems for Streetscapes, Chapter 10, Date of access:26.03.2015 Accessed at: https://www.sa.gov.au/_data/assets/pdf_ file/0010/19837/WSUD_chapter_10.pdf, 2015g.

17. Anonymous, New Jersey Stormwater Best Management Practices Manual, Date of access 26.03.2015. Accessed at: http://www.nj.gov/dep/stormwater/tier_A/pdf/NJ_ SWBMP_9.1\%20print.pdf, 2015h. 
18. J. Vymazal, Constructed Wetlands for Wastewater Treatment, Water, 2 (2010) 530-549.

19. Anonymous, Water Sensitive Urban Design Technical Manual Greater Adelaide Region, Constructed Wetlands, Chapter 13, Date of access: 27.03.2015. Accessed at: https://www.sa.gov.au/_data/assets/pdf_ file/0010/19099/WSUD_chapter_13.pdf, 2015।.

20. N. Karadeniz, Sultansazlığı Örneğinde Islak Alanlarının Çevre Koruma Açısından Önemi Üzerinde Bir Araştırma. Doktora Tezi, Ankara Üniversitesi, 1995.

21. Anonymous, Water Sensitive Urban Design Technical Manual Greater Adelaide Region, Rain Gardens,Green Roofs and Infiltration Systems, Chapter 6, Date of access: 30.03.2015. Accessed date: https://www. sa.gov.au/_data/assets/pdf_file/0011/11540/WSUD_ chapter_6.pdf, 2015i.

22. Islington, Promoting Sustainable Drainage Systems Design Guidance for Islington, Date of access: 02.04.2015. Accessed at: http://www.islington.gov. uk/publicrecords/library/Environmental-protection/ Information/Guidance/2011 2012/(2012-03-03)-SUDScover-and-contents.pdf, 2015.

23. Anonymous, Water Sensitive Urban Design Guidelines, For Individual Lots, Infill Development and Subdivision, Date of access : 29.03.2015. Accessed at: www. busselton.wa.gov.au/.../developercontrpl..., 2015j.

24. A. Graham, J. Day, B. Bray, S. Mackenzie, Sustainable drainage systems, Date of access:27.04.2015. Accessed at : http://www.rspb.org.uk/Images/SuDS_report_final_ tcm9-338064.pdf, 2015.

25. Anonymous, Water Sensitive Urban Design Technical Manual Greater Adelaide Region, Pervious Pavement, Chapter 7, Date of access: 01.04.2015. Accessed at https: //www.sa.gov.au/_data/assets/pdf_file/0019/9550/ WSUD_chapter_7.pdf, 2015k.

26. Urban Green-Blue Grids, Date of access: 03.05.2015. Accessed at: http://www.urbangreenbluegrids.com/ projects/waternet-office-amsterdam/, 2015.

27. Green Infrastructure Evidence Base, Date of access: 27.04.2015, Accessed at: http://gievidencebase. botanicgardens.sa.gov.au/contents/7-watermanagement., 2015.

28. G. Grant, Water Sensitive Urban Design (WSUD) Sustainable Drainage Systems (SUDS from theory to practice), Date of access:14.04.2015. Accessed at: http://www.gov.scot/resource/doc/1221/0120064.pdf, 2011.
29. Anonymous, Queens Botanical Garden Visitor and Administration Center, Date of access:07.04.2015. Accessed at: http://www.greenroofs.com/projects/ pview.php?id=653, 2015I.

30. SSI, The Sustainable sites initiative: The Case for Sustainable Landscapes, Date of access: 12.06.2013. Accessed at: http://www.sustainablesites.org/report/, 2009.

31. Queens Botanic Garden, Date of access: 15.11.2014. Accessed at: http://www.queensbotanical.org.,2014.

32. Beam Parklands, Beam Parklands Green Infrastructure Case Study, Date of access: 04.04.2015. Accessed at: file:///C:/Users/pc/Downloads/3466_Beam\%20 GI\%20Case\%20Study.pdf, 2015.

33. ARUP,. Design with water, Date of access: 12.02.2015. Accessed at: http://www.greenroofs.com/projects/ pview.php?id=653, 2013.

34. E2DESIGNLAB, Royal Park Wetland and Stormwater Harvesting System, Date of access: 29.03.2015. Accessed at: http://e2designlab.com.au/projects/ legacy-projects/i_31-royal-park-wetland-andstormwater-harvesting-system, 2015.

35. DAC\&CITIES, Upton: Drainage Scheme Makes for Peace of Mınd In Urban Extension, Date of access: 25.04.2015. Accessed at: http://www.dac.dk/en/dac-cities/ sustainable-cities/all-cases/water/upton-drainagescheme-makes-for-peace-of-mind-in-urban-extension/, 2015.

36. A. A., Karadağ, O., Uzun, Watershed Management And Its Effects On Turkey's Trans-Boundary Water Policies. International Davraz Congress On Social and Economic Issues Shaping The World's Future: New Global Dialogue. University of Süleyman Demirel, (2009), Isparta, Turkey.

37. Devlet Su İşleri Genel Müdürlüğü, Tarım (Sulamanın Önemi).Date of access: 18.01.2013,Accessed at: DSi Genel Müdürlüğü. www.dsi.gov.tr/docs/hizmet-alanlari/ tarim-sulama.pdf?sfvrsn=2, 2012. 
